\title{
Hubungan Pengetahuan dan Kemampuan Ekonomi Masyarakat Terhadap Aksesibilitas BPJS
}

\author{
Wisnu Probo Wijayanto \\ Program Studi Ilmu Keperawatan STIKes Aisyah Pringsewu Lampung \\ Jl. A. Yani No. IA Tambahrejo Kecamatan Gadingrejo Kabupaten Pringsewu \\ Lampung 35372 Indonesia Telp.0729333343 \\ Email: inuasawijaya.ww@gmail.com
}

\begin{abstract}
ABSTRAK
BPJS merupakan badan hukum dengan tujuan yaitu mewujudkan terselenggaranya pemberian jaminan untuk terpenuhinya kebutuhan dasar hidup yang layak bagi setiap peserta dan anggota keluarganya. Penelitian ini bertujuan untuk mengetahui hubungan pengetahuan dan kemampuan ekonomi masyarakat terhadap aksesibilitas BPJS. Desain yang digunakan dalam penelitan ini adalah analitik dengan pendekatan cross Sectional. Subjek penelitian ini adalah kepala keluarga atau anggota keluarga di Desa Kahuripan. Teknik pengambilan sampel menggunakan random sampling di peroleh sebanyak 218 orang. Analisa data bivariat menggunakan uji chi square. Hasil penelitian menunjukkan ada hubungan antara Pengetahuan dengan Aksesibilitas BPJS ( $p$ value $=0,001, O R=2,898$ ) dan ada kemampuan ekonomi dengan aksesibilitas BPJS. ( $p$ value $=0,006, O R=2,316$ ). Sosialisasi mengenai program BPJS Perlu dilaksanakan agar masyarakat memiliki pemahaman yang lebih baik lagi sehingga kesulitan-kesulitan dalam mengakses BPJS dapat dihindari.
\end{abstract}

Kata Kunci : Pengetahuan, Ekonomi dan Aksesibilitas BPJS Kesehatan.

\section{CORRELATIONS OF KNOWLEDGE AND ECONOMIC ABILITY OF SOCIETY TO ACCESSIBILITY OF BPJS}

\begin{abstract}
BPJS is a legal entity with the aim of realizing the implementation of providing guarantees for the fulfillment of basic needs of decent living for each Participant and members of his family. This study aims to determine the relationship of knowledge and economic ability of society to the accessibility of BPJS. The design used in this research is analytical with cross sectional approach. The subject of this study is the head of the family or family members in the family in the village of Kahuripan. Sampling technique using random sampling was obtained as many as 218 people. Analysis of bivariate data using chi square test. The results obtained There is a relationship Knowledge with Accessibility BPJS ( $p$ value $=0.001, O R=2.898$ ) and there is a relationship economic capability with Accessibility BPJS ( $p$ value $=0.006$, OR =2,316). Socialization about the BPJS program Need to be implemented so that people have a better understanding so that difficulties in accessing BPJS can be avoided.
\end{abstract}

Keywords: Knowledge, Economics and Accessibility of BPJS Health.

How to Cite: Wijayanto, W. P. (2017). Hubungan Pengetahuan dan Kemampuan Ekonomi Masyarakat Terhadap Aksesibilitas Bpjs. Jurnal Aisyah: Jurnal Ilmu Kesehatan. 2 (2), 131 - 140. 


\section{PENDAHULUAN}

Setiap orang memiliki risiko jatuh sakit dan membutuhkan biaya cukup besar ketika berobat ke rumah sakit.Apalagi, jika sakit yang dideritanya merupakan penyakit yang kronis atau tergolong berat.Untuk memberikan keringanan biaya, pemerintah mengeluarkan Program JKN (Jaminan Kesehatan Nasional).Program pelayanan kesehatan yang merata dan tidak diskriminatif, diatur dalam Undang-undang Nomor 40 tahun 2004 tentang Sistem Jaminan Sosial Nasional (SJSN) (Kemenkes, 2014).

BPJS merupakan badan hukum dengan tujuan yaitu mewujudkan terselenggaranya pemberian jaminan untuk terpenuhinya kebutuhan dasar hidup yang layak bagi setiap Peserta dan anggota keluarganya.Namun demikian hingga saat ini, berbagai tantangan dan kendala bermunculan dalam pelaksanaan BPJS. Berbagai tantangan dan kendala ini antara lain: kurangnya infrastruktur di daerah, peralatan dan perlengkapan yang masih belum ada dan terdistribusi di daerah, kurangnya sumber daya manusia yang siap untuk melakukan pelayanan (Kompas, 2014).

Pemerintah Indonesia mengklaim peserta BPJS pada bulan Oktober tahun 2014 mencapai 130 juta jiwa peserta BPJS, angka ini memang mengalami peningkatan $10 \%$ dari bulan sebelumnya yaitu 127 juta jiwa peserta BPJS pada bulan Agustus, tetapi angaka tersebut belum mencapai target jangka pendek yang ditentukan pada tahun 2014 sebesar 131 juta peserta BPJS dan masih jauh dari target jangka panjang yaitu semua penduduk Indonesia yang berjumlah 257,5 juta jiwa terdaftar menjadi peserta BPJS pada tahun 2019 (Purnamasari, 2014).

Program BPJS di propinsi Lampung disambut positif oleh masyarakat Lampung hal ini dibuktikan dengan jumlah peserta BPJS pada tahun 2014, tercatat sebanyak 3.803.943 jiwa di Provinsi Lampung terdaftar dalam penerima BPJS Kesehatan. Akan tetapi data tersebut masih belum seluruh masyarakat propinsi lampung (http://lampung.antaranews.com/, diakses tanggal 25 Februari, 2015).

Kabupaten Tulang Bawang mulai berlakukan Program Jaminan Kesehatan Nasional (JKN) per 1 Januari 2014.Dengan berlakunya program tersebut, maka istilah Jamkesmas, Jamkesta, Jampersal, Asabri dan Askes PNS sudah melakukan penyesuaian menjadi Badan Penyelenggara Jaminan Sosial (BPJS). Penduduk Kabupaten Tulang Bawang menurut data dari BPS adalah 402.226 jiwa yang ditanggung Jamkesmas adalah 125.302 jiwa, Askes sosial 11.219 jiwa, Jamsostek 26.716 jiwa (PemKab, Tulang bawang, 2014).

Menurut Anderson dalam Notoatmodjo (2007) faktor yang berhubungan dengan pemanfaatan fasilitas kesehatan dalam hal ini adalah BPJS diataranya adalah pengetahuan dan status ekonomi. Pengetahuan merupakan hasil tahu setelah melakukan pengindraan seseorang dengan pengetahuan baik memiliki pondasi yang baik untuk melakukan sesuatu yang bersifat langgeng sedangkan tingkat ekonomi seseorang akan mempengaruhi kemampuan untuk mengakses pelayanan kesehatan yang ada.

Berdasarkan hasil prasurvey yang peneliti lakukan di desa Kahuripan Jaya Kecamatan Banjar Baru Kabupaten Tulang Bawang pada tanggal 1 Februari 2015, terhadap 20 warga, terdapat 15 (75\%) belum mengikuti program BPJS dari 15 orang tersebut 10 diantaranya kurang mengetahui tentang cara melakukan pendaftaran BPJS dan 15 dari 20 orang tersebut mengatakan berprofesi sebagai buruh tani dan pendapatan perbulan dibawah 1 juta rupiah sedangkan upah minimum kabupaten Tulang Bawang tahun 2015 1,6 Juta perbulan. Sedangkan 5 $(25 \%)$ dari 20 warga yang diwawancari telah memiliki akses BPJS karena telah di 


\section{Jurnal Aisyah: Jurnal Ilmu Kesehatan 2 (2) 2017, - 133}

Wisnu Probo Wijayanto

ikut sertakan dari kantornya karena bekerja sebagai karyawan swasta.

Berdasarkan uraian diatas dapat di rumuskan pertanyaan penelitian "Bagaimanakah hubungan Pengetahuan dan Kemampuan Ekonomi Masyarakat terhadap Aksesibilitas BPJS pada Masyarakat di Desa Kahuripan Jaya Kecamatan Banjar Baru Kabupaten Tulang Bawang?”.

\section{METODE PENELITIAN}

Jenis penelitian ini adalah penelitian kuantitatif, yaitu penelitian yang digunakan untuk meneliti pada populasi atau sampel tertentu, pengumpulan data menggunakan instrumen penelitian, analisis data bersifat kuantitatif dengan tujuan untuk menguji hipotesis yang telah ditetapkan (Sugiyono, 2009).

Penelitian dilakukan di Desa Kahuripan Jaya Kecamatan Banjar Baru Kabupaten Tulang Bawang pada bulan Juli Tahun 2015.Populasi dalam penelitian ini adalah seluruh kepala keluarga atau anggota kelauarga yang paling berpengaruh di keluargadi Desa Kahuripan Jaya Kecamatan Banjar Baru Kabupaten Tulang Bawang Tahun 2015 sebayak 475 Kepala Keluarga dan diambil sebanyak 218 sampel dengan mengggunakan teknik random samling.

Variabel independent pada penelitian ini adalah pengetahuan dan Kemampuan Ekonomi sedangkan variabel dependent yang diteliti pada penelitian ini adalah aksesibilitas BPJS.

Analisa data pada penelitia ini menggunakan analisa univariat dengan rumus persentase bertujuan untuk mengetahui distribusi frekuensi masingmasing variablel sedangan untuk mengetahui hubungan antar variabel dalam penelitian ini menggunakan analisa bivariat menggunakan uji chi square. Taraf kesalahan yang digunakan adalah 5\%, untuk melihat hasil kemaknaan perhitungan statistik digunakan batas kemaknaan 0,05. Berarti jika $\mathrm{p}$ value $\leq 0,05$ maka hasilnya bermakna yang artinya Ho ditolak dan $\mathrm{Ha}$ diterima.

\section{HASIL DAN PEMBAHASAN}

Aksesibilitas BPJS.

Berdasarkan hasil penelitian dapat diketahui dari 218 responden yang tidak mengakses BPJS sebesar 146 orang (67\%) dan yang mengakses BPJS sebesar 72 orang (33\%).

Aksesibilitas yaitu suatu ukuran potensial atau kesempatan untuk melakukan sesuatu dalam pencapaian kebutuhan. Aksesibilitas juga dapat diartikan berarti kemudahan melakukan aktivitas pada suatu lingkungan tertentu secara aman, nyaman, mandiri, bebas dan aktif (Kemenkes, 2013).

Menurut Anderson dalam Notoatmodjo (2007) faktor yang berhubungan dengan pemanfaatan fasilitas kesehatan dalam hal ini adalah BPJS diataranya adalah pengetahuan dan status ekonomi.

Hasil ini sejalan dengan penelitian Littik, (2005) hasil penelitian didapat faktor-faktor yang berhubungan dengan kepemilikan asuransi di Propinsi NTT adalah umur (untuk Jamsostek) dengan $p$ value $=0,002$, tingkat pendidikan dan wilayah (untuk semua tipe asuransi kecuali JPKM) dengan $p$ value $=0,004$, pendapatan (untuk Askes) dengan $p$ value $=0,001$, serta jarak dan transportasi (untuk Askes dan Jamsostek) dengan pvalue $=0,001$.

Berdasarkan hasil penelitian dan teori diatas peneliti perpendapat bahwa sebagian besar masyarakat desa Kahuripan Jaya Kecamatan Banjar Baru Kabupaten Tulang Bawang tahun 2015 banyak yang tidak mengakses BPJS disebabkan karena kurangnya pengetahuan masyarakat mengenai program BPJS karena tidak adanya informasi yang diterima oleh masyarakat mengenai BPJS Kesehatan. Hasil wawancara terhadap responden yang tidak mengakses BPJS mengatakan di Desa Kahuripan selama ini tidak pernah diadakan penyuluhan mengenai BPJS Kesehatan 


\section{Jurnal Aisyah: Jurnal Ilmu Kesehatan 2 (2) 2017, - 134}

Wisnu Probo Wijayanto

selain itu petugas kesehatan dan tempat pelayanan kesehatan setempat juga hanya mengarahkan masyarakat yang melakukan kunjungan pengobatan saja yang di sarankan untuk memiliki BPJS kesehatan, sehingga masyarakat yang tidak pernah melakukan kunjungan pengobatan tidak mengetahui adanya progam BPJS kesehatan.

Kemugkinan ke dua masyarakat di desa Kahuripan Jaya sebagian besar memiliki tingkat ekonomi yang rendah, sehingga masyarakat berfikir lebih baik menggunakan uangnya untuk memenuhi kebutuhan sehari-hari dari pada di gunakan untuk mebayar iyuran BPJS.Berdasarkan fenomena diatas maka perlu dilakukan penyuluhan kepada masyarakat mengenai program BPJS hal ini bertujuan untuk meningkatkan ke ikutsertaan masyarakat terhadap aksebilitas BPJS kesehatan.

\section{Pengetahuan masyarakat tentang BPJS.}

Berdasarkan data hasil penelitian dapat diketahui dari 218 responden ada sebesar 134 orang $(61,5 \%)$ yang memiliki pengetahuan kurang baik dan 84 orang $(38,5 \%)$ memiliki pengetahuan baik.

Pengetahuan merupakan hasil tahu dan ini terjadi setelah orang melakukan penginderaan terhadap suatu objek tertentu.Penginderaan terjadi melalui panca indera manusia, yaitu indera penglihatan, indera pendengaran, indera penciuman, indera perasa dan indera peraba.Pengetahuan atau kognitif merupakan domain yang sangat penting dalam membentuk tindakan seseorang (Notoatmodjo, 2010).

Hasil ini sejalan dengan penelitian Littik, (2005) hasil penelitian didapat faktor-faktor yang berhubungan dengan kepemilikan asuransi di Propinsi NTT adalah umur (untuk Jamsostek) dengan $p$ value $=0,002$, tingkat pendidikan dan wilayah (untuk semua tipe asuransi kecuali JPKM) dengan $p$ value $=0,004$, pendapatan (untuk Askes) dengan $p$ value $=0,001$, serta jarak dan transportasi (untuk Askes dan Jamsostek) dengan pvalue $=0,001$.

Peneliti berpendapat rendahnya pengetahuan masyarakat di Desa Kahuripan Kecamatan Banjar Baru Kabupaten Tulang Bawang mengenai BPJS kesehatan disebabkan tidak adanya sosialisasi langsung mengenai BPJS yang disampaikan oleh petugas dinas kesehatan ataupun puskesmas kepada masyarakat. Sehingga sebagian besar responden tidak bisa menjawab pertanyaan mengenai pengetahuan BPJS kesehatan yang peneliti berikan.Informasi BPJS Kesehatan hannya disampaikan melalui media masa seperti televisi dan juga baleho atau sepanduk yang ada di tempat-tempat strategis biasanya didaerah perkotaan, hal ini yang menyebabkan sebagian besar masyarakat desa tidak mengetahui adanya program BPJS kesehatan.

Kurangnya pengetahuan mengenai BPJS Kesehatan juga dapat dipengaruhi oleh rendahnya tingkat pendidikan masyarakat, sebagian besar responden memiliki pendidikan hanya hingga SMP. Rendahnya pedidikan masyarakat dapat berpengaruh terhadap daya tangkap terhadap informasi BPJS kesehatan yang diperoleh tidak dapat di pahami, sehingga walaupun masyarakat pernah melihat atau mendengar informasi mengenai BPJS Kesehatan mereka akan mengabaikannya karena merasa informasi tersebut tidak terlalu penting.

Oleh karena itu penting dilakukan penyuluhan secara langsung dan berkala tidak hanya dilakukan sekali saja kepada masyarakat mengenai BPJS Kesehatan sehingga masyrakat pedesaan mengerti betul maskud tujuan dan manfaat dari penyelengaraan BPJS Kesehatan.

\section{Tingkat ekonomi masyarakat.}

Berdasarkan data hasil penelitian pada tabel 4.3 diatas dapat diketahui dari 218 responden ada sebesar 121 orang $(55,5 \%)$ 


\section{Jurnal Aisyah: Jurnal Ilmu Kesehatan 2 (2) 2017, - 135}

Wisnu Probo Wijayanto

yang kemampuan ekonominya kurang dari UMK dan 97 orang $(44,5 \%)$ yang kemampuan ekonominya setara atau lebih dari UMK.

Menurut Anderson dalam Notoatmodjo (2007) faktor yang berhubungan dengan pemanfaatan fasilitas kesehatan dalam hal ini adalah BPJS diataranya adalah pengetahuan dan status ekonomi. Tingkat ekonomi seseorang akan mempengaruhi kemampuan untuk mengakses pelayanan kesehatan yang ada.

Hasil ini sejalan dengan penelitian Littik, (2005) hasil penelitian didapat faktor-faktor yang berhubungan dengan kepemilikan asuransi di Propinsi NTT adalah umur (untuk Jamsostek) dengan $p$ value $=0,002$, tingkat pendidikan dan wilayah (untuk semua tipe asuransi kecuali JPKM) dengan value $=0,004$, pendapatan (untuk Askes) dengan $p$ value $=0,001$, serta jarak dan transportasi (untuk Askes dan Jamsostek) dengan pvalue $=0,001$.

Berdasarkan hasil penelitian dan teori diatas menurut peenliti rendahnya ekonomi masyarakat di Desa Kahuripan Jaya Kecamatan Banjar Baru Kabupaten Tulang Bawang tahun 2015, dapat menyebabkan mereka tidak mampu untuk mengases BPJS Kesehatan karena tidak memiliki biaya untuk membayar iyuran pada tiap bulannya. Sebagian besar masyarakat desa Kahuripan hanya berpropesi sebagai buruh tani yang pengasilannya tiak menentu dan masih dibawah standar UMK, sehingga mereka lebih memilih memenuhi kebutuhan rumah tangga daripada harus mengikuti program asuransi kesehatan BPJS yang menurut mereka memberratkan karena harus membayar setiap bulannya.

BPJS Kesehatan sebenarnya tidak sepenuhnya harus membayar iyuran rutin, karena pemerintah telah menerapkan program BPJS Kesehatan gratis bagi masyarakat yang tidak mampu, akan tetapi karena tidak adanya sosialisasi kepada masyarakat desa Kahuripan mengenai program BPJS Gratis tersebut sehingga sebagian besar masyarakat memiliki persepsi yang salah yaitu semua asuransi kesehatan pasti diharuskan membayar iyuran pada setiap bulannya.

BPJS Kesehatan wajib dimiliki semua lapisan masyarakat dan mereka yang tidak mampu untuk membayar iyuran juga berhak untuk mengases nya dengan tangguangan biaya dari pemerintah.Diharapkan pada pemerintah daerah setemat dapat melakukan sosialisasi secara merata pada masyarakat dan diperlukan pengawasan terhadap pelaksanaan supaya program BPJS dapat diterima oleh masyarakat yang benar-benar membutuhkan.

\section{Hubungan Pengetahuan dengan Aksesibilitas BPJS pada Masyarakat}

Hasil uji statistik chi square didapat nilai $p$ value $=0,010(0,001<0,05)$, maka dapat disimpulkan ada hubungan Pengetahuan dengan Aksesibilitas BPJS pada Masyarakat di Desa Kahuripan Jaya Kecamatan Banjar Baru Kabupaten Tulang Bawang Tahun 2015. OR didapat 2,898 artinya responden yang memiliki memiliki pengetahuan baik memiliki peluang untuk mengakses BPJS sebesar 2,898 kali dibandingkan dengan responden yang memiliki pengetahuan kurang baik.

Menurut teori Notoatmodjo (2010) perilaku yang didasari oleh pengetahuan akan lebih lama dari pada yang tidak didasari oleh pengetahuan. Pengetahuan seseorang sangat berpengaruh dalam perilaku karena pengetahuan merupakan hasil tahu dan ini terjadi setelah seseorang melakukan pengindraan terhadap suatu objek tertentu.

Hasil ini sejalan dengan penelitian Juhaini (2010) mengenai Potensi Partisipasi Masyarakat Menuju Pelaksanaan Jaminan Kesehatan Dalam Rangka Universal Coverage di Kota Bandung.Hasil penelitian menunjukkan bahwa sebagian besar (94.4\%) responden belum memiliki 


\section{Jurnal Aisyah: Jurnal Ilmu Kesehatan 2 (2) 2017, - 136}

Wisnu Probo Wijayanto

tabungan kesehatan.Selanjutnya, 87.1\% responden menyatakan mau ikut asuransi kesehatan dengan pelayanan kesehatan lengkap sampai ke tingkat Rumah Sakit. Hasil uji statistik didapat $p$ value $=0,003$, dinyatakan ada hubungan partisipasi masyarakat dengan program Universal Coverage di Kota Bandung.

Berdasarkan hasil penelitian peneliti berpendapat rendahnya masyarakat desa kahuripan yang memiliki aksesibilitas BPJS Kesehatan disebabkan karena tidak adanya informasi yang menyeluruh dari petugas kesehatan kepada masyarakat secara langsung. Menurut masyarakat setempat selama ini mereka mengetahui informasi BPJ kesehatan hanya dari media iklan televisi yang mereka tonton, bagi yang tidak memiliki televisi mereka tidak mengetahui sama sekali tentang Program BPJS kesehatan.

Informasi yang didapat dari media masa seperti televisi tidak didapat secara utuh sehingga masyarakat kebingungan kepada siapa dalam menayakakan maksud dan tujuan dari program BPJS tersebut.

Program BPJS kesehatan sangat bermanfaat bagi seluruh lapisan masyarakat untuk menjamin kesehatan masyarakat sehingga diharapkan bagi pemerintah dapat mensosialisasikan secara langsung program BPJS dengan tenaga penyuluh yang memadai baik dari segi pendidikan dan pengalaman sehingga minat masyarakat dapat meningkat dalam mengakses BPJS Kesehatan

Hubungan Kemampuan Ekonomi dengan Aksesibilitas BPJS pada Masyarakat

Hasil penelitiandapat pada tabel 4.5 tentang hubungan Kemampuan Ekonomi dengan Aksesibilitas BPJS pada Masyarakat di Desa Kahuripan Jaya Kecamatan Banjar Baru Kabupaten Tulang Bawang Tahun 2015, dapat diketahui bahwa 91 responden (75,2\%) Kemampuan Ekonomi kurang dari UMK tidak mengakses BPJS, sedangkan 55 responden $(56,7 \%)$ yang kemampuan ekonomi setara dengan UMK tidak mengakses BPJS. Hasil uji statistik chi square didapat nilai $p$ value $=0,006(0,006<$ 0 , 05), maka dapat disimpulkan ada hubungan Kemampuan Ekonomi dengan Aksesibilitas BPJS pada Masyarakat di Desa Kahuripan Jaya Kecamatan Banjar Baru Kabupaten Tulang Bawang Tahun 2015, dengan nilai OR didapat 2,316 artinya responden yang memiliki kemampuan ekonomi setara dengan UMK berpeluang mengakses BPJS sebesar 2,316 kali dibandingkan dengan responden yang memiliki kemampuan Ekonomi kurang dari UMK.

Menurut Anderson dalam Notoatmodjo (2007) faktor yang berhubungan dengan pemanfaatan fasilitas kesehatan dalam hal ini adalah BPJS diataranya adalah pengetahuan dan status ekonomi. Tingkat ekonomi seseorang akan mempengaruhi kemampuan untuk mengakses pelayanan kesehatan yang ada.

Hasil ini sejalan dengan penelitian yang dilakukan oleh Littik, (2005) dengan judul Faktor-faktor yang berhubungan dengan kepemilikan Asuransi di Provinsi Nusa Tenggara Timur Hasil studi menunjukkan bahwa terdapat hubungan antara pendapatan (untuk Askes) dengan kepemilikan asuransi kesehatan dengan $p$ value $=0,001$.

Sedangkan penelitian Juhaini (2010) tentang Potensi Partisipasi Masyarakat Menuju Pelaksanaan Jaminan Kesehatan Dalam Rangka Universal Coverage di Kota Bandung menyatakan sebagian besar (94.4\%) responden belum memiliki tabungan kesehatan.Selanjutnya, $87.1 \%$ responden menyatakan mau ikut asuransi kesehatan dengan pelayanan kesehatan lengkap sampai ke tingkat Rumah Sakit. Hasil uji statistik didapat $p$ value $=0,003$, dinyatakan ada hubungan partisipasi masyarakat dengan program Universal Coverage di Kota Bandung. 
Berdasarkan teori dan hasil penelitian diatas menurut peneliti adanya hubungan antara kemampuan ekonomi dengan aksesibilitas BPJS kesehatan di desa Kahuripan Jaya kemungkinan disebabkan karena masyarakat beranggapan bahwa mereka lebih mementingkan kebutuhan pokok sandang, papan dan pangan, sedangkan asuransi kesehatan belum menjadi kebutuhan pokok pada masyarakat.

Menurut masyarakat desa Kahuripan Jaya Asuransi kesehatan merupakan hal yang sangat asing bagi mereka karena biasanya asuransi kesehatan hanya dimiliki oleh orang yang memiliki ekonomi tinggi atau sudah mapan.Sedangkan untuk masyarakat dengan ekonomi kebawah tidak diwajibkan untuk memiliki asuransi kesehatan seperti BPJS.

Masih banyaknya masyarakat yang belum mengetahui tentang program BPJS kesehatan sehingga mereka salah mepersepsikan BPJS kesehatan yang disamakan dengan asuransi kesehatan suasta pada umumnya, sehingga mereka beranggapan bahwa bila memiliki program BJS kesehatan akan mengeluarkan biaya yang besar untuk membayarnya.

\section{KESIMPULAN DAN SARAN}

Berdasarkan hasil analisis dan pembahasan, maka dapat disimpulkan bahwa Masyarakat desa Kahuripan Jaya yang tidak mengakses BPJS sebesar 146 (67\%) orang. Masyarakat Kahuripan Jaya yang memiliki pengetahuan kurang baik tentang BPJS sebesar 134 (61,5\%). Masyarakat Kahuripan Jaya yang memiliki kemampuan ekonomi kurang dari UMK sebesar $121(55,5 \%)$ orang. Ada hubungan Pengetahuan dengan Aksesibilitas BPJS ( $p$ value $=0,001, \mathrm{OR}=$ 2,898). dan kemampuan ekonomi dengan Aksesibilitas BPJS ( $p$ value $=0,006, \mathrm{OR}=$ 2,316) pada Masyarakat di Desa Kahuripan Jaya Kecamatan Banjar Baru Kabupaten Tulang Bawang.
Hasil penelitian ini dapat menambah wawasan peneliti mengenai hubungan pengetahuan dan kemampuan ekonomi dengan aksesibilitas BPJS, sehingga peneliti sebagai calon tenaga kesehatan dapat mengaplikasikan hasil penelitian dalam masyarakat untuk menjelaskan tentang BPJS yang bertujuan untuk meningkatkan derajat kesehatan masyarakat.

Bagi Institusi kesehatan setempat agar melakukan sosialisasi pada terhadap masyarakat tentang BPJS supaya masyarakat mengerti tentang program BPJS dan melakukan aksesibilitas BPJS.

Penelitian selanjutnya dapat dapat melakukan studi lanjutan tentang faktorfaktor yang mempengaruhi aksesibilitas BPJS pada masyarakat dan faktor lain yang mempengaruhi pengetahuan kepala keluarga tentang BPJS seperti dukungan petugas kesehatan 


\section{Jurnal Aisyah: Jurnal Ilmu Kesehatan 2 (2) 2017, - 138}

Wisnu Probo Wijayanto

\section{DAFTAR PUSTAKA}

Anonim. (2012). Pengertian Umum Aksesibulitas. Dalam http://www.penataanruang.net/.pdf diaskes tanggal 17 juni 2014.

Arikunto, Suharsimi. (2006). Prosedur Penelitian Suatu Pendekatan Praktik. Jakarta: Rineka Cipta.

Badan Pusat Statistik. (2013). Badan Pusat Statistik Indonesia tahun 2013. dalam www.bps.go.id.

BPJS Lampung. (2014). Peserta BPJS Propinsi Lampung Meningkat Drastis. Dalam http://lampung.antaranews.com/, diakses tanggal 25 Februari, 2015.

BPS Pemkab Tulang Bawang. (2015). Upah Minimum Kabupaten Tulang Bawang tahun 2015. Dalam http://tulangbawangkab.go.id/.

Eryando. (2007). Aksesibilitas Kesehatan Maternaldi Kabupaten Tangerang, 2006. Makara, Kesehatan, Vol. 11(2), desember 2007: 76-83.

Handayani. (2014). Faktor-faktor yang memengaruhi kemauan masyarakat untuk membayar iuran jaminan kesehatan di Kabupaten Hulu Sungai Selatan. www.jurnalkesehatan.com.

Hastono, Sutanto Priyo. (2007). Analisis Data Kesehatn. Jakarta: FKM UI.

Jahid. (2013). Faktor yang berhubungan dengan kepuasan pasien peserta jamkesmas pada ruang rawat inap di rumah sakit Elim Rantepao kabupaten Toraja Utara. Skripsi. UNHAS: Tidak dipublikasikan.
Juhaini. (2010). Potensi Partisipasi Masyarakat Menuju Pelaksanaan Jaminan Kesehatan Dalam Rangka Universal Coverage di Kota Bandung.

www.jurnalkesehatan.com.

Kemenkes. (2013). Program Indonesia Sehat untuk atasi masalah kesehatan. Dalam http://www.depkes.go.id/article/vie $\mathrm{w} / 15020400002 /$ program-indonesiasehat-untuk-atasi-masalah-

kesehatan.html. Diakses tanggal 15 Juni 2015.

Kompas. (2014). Pemerintah banyak mengalami Kendala Penyelenggaraan BPJS Kesehatan. Dalam http//kompas.bpjs.kendala// diakses tanggal 1 Januari 2015.

Littik. (2005). Faktor-faktor yang berhubungan dengan kepemilikan Asuransi di Provinsi Nusa Tenggara Timur. www.jurnalkesehatan.com.

Misnaniarti. (2014). Analisis Kebijakan Pemerintah Daerah Dalam Pengembangan Jaminan Sosial Kesehatan Sumatera Selatan Semesta'Menyambut Universal Health Coverage. Palembang: Skripsi Unsri.

Notoatmodjo. (2010). Ilmu Perilaku Kesehatan. Jakarta: PT Rineka Cipta.

Notoatmodjo. (2010). Metodologi Penelitian Kesehatan. Jakarta: PT Rineka Cipta.

Notoatmodjo, S. (2007). Promosi Kesehatan dan Ilmu Perilaku. Jakarta: Rineka Cipta.

Pemkab Tulangbawang. (2014). Kabupaten Tulang Bawang mulai berlakukan 


\section{Jurnal Aisyah: Jurnal Ilmu Kesehatan 2 (2) 2017, - 139}

Wisnu Probo Wijayanto

Program Jaminan Kesehatan

Nasional (JKN) per 1 Januari 2014.

Dalam

http://tulangbawangkab.go.id/?tag=b pjs.

Pertiwi. (2012). Minat Pemanfaatan Pelayanan Kesehatan Bagi Peserta Program Jaminan Kesehatan Bali Mandara Studi di Kabupaten Karangasem dan $K$ Abupaten Badung. Tesis: Universitas Gajah Mada.

Provinsi Jawa Timur. (2014). RPJMD Propinsi Jawa Timur 2009-2014. Dalam http://bappeda.jatimprov.go.id/2014/ 01/27/evaluasi-pelaksanaan-rpjmd2009-2014/. Diakses tanggal 15 Juni 2015 .

Purnamasari. (2014). Jumlah Peserta Meningkat, BPJS Tingkatkan Distribusi Fasilitas Kesehatan.

Dalam

http://health.detik.com/read/2014/.

Putong, Iskandar. (2008). Economics, Pengantar Mikro dan Makro, Edisi Kedua. Jakarta: Mitra Wacana Media.

Santrock, John W. (2007). Psikologi Pendidikan Edisi Kedua. Jakarta: Prenada Media Group.

Sugiyono. (2009). Metode Penelitian Kuantitatif dan Kualitatif. Bandung: CV Alphabeta.

Suharso dan Ana Retnoningsih. (2005). Kamus Besar Bahasa Indonesia. Semarang: CV. Widya Karya.

Undang-Undang (UU) Nomor 24 Tahun 2011. Tentang Badan Pengelola Jaminan Sosial (BPJS). Kemenkes
RI $2014 . \quad$ Dalam

www.hukumonline.com.

UU RI No. 20 Tahun 2003 pasal 1. Pengertian Pendidikan. Dalam www.hukumonline.com diakses tanggal 1 Januari 2015. 
Jurnal Aisyah: Jurnal Ilmu Kesehatan 2 (2) 2017, - 140

Wisnu Probo Wijayanto 